КОМПЮТЬРНА ПЕРИМЕТРИЯ. КЛИНИЧНА ИНТЕРПРЕТАЦИЯ

НА ПЕРИМЕТРИЧНАТА НАХОДКА В ПОЛЗА НА ТОПИЧНАТА ДИАГНОЗА (II ЧАСТ)

Д. Митова

Очна клиника “Света Петка" - Варна

\title{
COMPUTED PERIMETRY. CLINICAL INTERPRETATION OF PERIMETRIC FINDING FOR THE BENEFIT OF TOPICAL DIAGNOSIS (PART II)
}

\author{
D. Mitova \\ Eye Clinic "Sv. Petka" - Varna
}

Настоящото изложение има за цел да даде диференциалнодиагностични насоки при определени типове периметрични дефекти, да ориентира в локализацията на патологичния процес и да подпомогне диагностиката.

Периметричната находка може да се обособи в няколко типа според анатомичната локализация на патологичния процес:

1. Ретинална патология

2. Зрителен нерв (Optic nerve-type defects)

3. Хиазмален тип (правило на кръстосването "Rules of the road")

4. Трактусов тип (Optic tract + корпус геникулатум латерале - LGN)

5. Париетален и темпорален дял (сепарация по типа-горе)

6. Окципитални дефекти.

В някои случаи дефектите са сходни и е важно да се знаят диференциалнодиагностичните ключове. Такава е връзката на периметричния дефект с фиксационната точка при неврологични лезии, за разлика от ретиналните и тези на зрителния нерв, които са свързани със сляпото петно. Неврологичните дефекти респектират вертикалния меридиан и по правило са двустранни (с малки изключения), докато заболяванията на ретината и зрителния нерв респектират хоризонталния меридиан и по-често са едностранни. Нарушенията в зеничните реакции, както и съпътстваща неврологична симптоматика, включително ангажиране на други черепномозъчни нерви, може също да даде ключ за топичната диагноза. Наличието на видима атрофия в папилата говори за дефекти преди корпус геникулатум латерале. Асиметрията в оптокинетичния нистагъм (OKN) може да разграничи париетална от окципитална лезия. Конгруентността на дефектите също е насочваща.

\section{ПЕРИМЕТРИЧЕН ДЕФЕКТ ПРИ ЗАСЯГАНЕ НА РЕТИНАТА}

При ретинална патология находката може да бъде монокулярна или бинокулярна, като тя винаги има офталмоскопско съответствие. Верифициране на находката трябва да се направи с ФА (флуоресцеинова ангиография) и FAF (фундусова автофлуоресценция),

Периметрични дефекти, свързани с ретинална патология, най-често са обект на ДД при неврологична симптоматика. Те не респектират вертикалния меридиан и често са неправилни. Централните скотоми могат да 
се дължат на макулна патология - CNV, географска атрофия, хлорокинова интоксикация. Обширната географска атрофия със запазен централен остров може да имитира пръстеновиден или хемианопсичен скотом.

Двустранни централни скотоми има при хлорокинова макулопатия. Изследва се с централна програма (10-2/M). Допълнителни ранни клинични белези могат да се уловят c FAF. В диференциалнодиагностичен план трябва да се мисли за двустранен неврит, друга макулна патология (конусчева дистрофия - тя има характерен вид на ОСТ; географска атрофия, CNV), както и изолирани лезии в окципиталния дял.
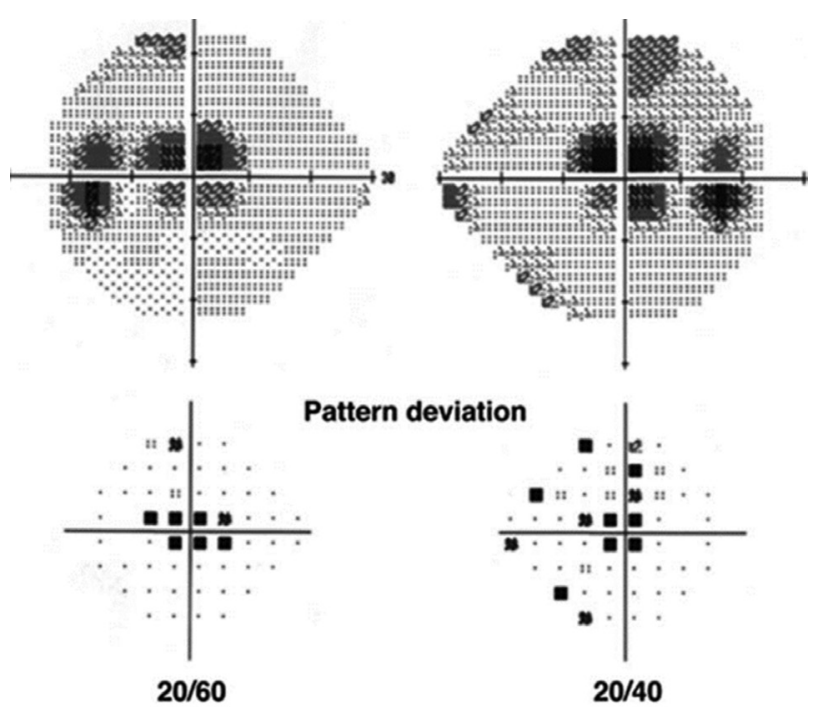

Фиг. 1. Двустранни централни скотоми

Съдовата патология на ретината дава също специфика в периметричната находка. Най-често се касае за клонови или стволови оклузии на артерия или вена централис. Тяхното разположение следва хода на съдовите дъги и респектира рафето. Така се оформят алтитудинални дефекти при клоново засягане, които обаче не са с резки граници. Резки граници на алтитудиналния дефект и връзка със сляпото петно се получават при исхемичните оптикопатии.

\section{ПЕРИМЕТРИЧНИ ДЕФЕКТИ ПРИ ЗАСЯГАНЕ НА ЗРИТЕЛНИЯ НЕРВ (OPTIC NERVE-TYPE)}

Влакната на зрителния нерв започват от ганглийните клетки, с най-висока концентрация в централните $30^{\circ}$ на фундуса (макулата), имат дъговиден ход и се организират в папилата на зрителния нерв. Неврофибриларните дефекти са три типа:

- При засягане на папиломакулния сноп, който завършва в темпоралната част на папилата, може да е налице централен, парацентрален или цекоцентрален дефект.

- При засягане на аркуатните влакна се формира аркуатен скотом (влакната от горнотемпоралната ретина завършват в горната половина на папилата, а от долнотемпоралната - в долната половина). Скотом на Seidel (дъговидно издължаване на сляпото петно) се получава при засягане на проксималната част в близост до папилата, а назална стъпка - при ангажиране на дисталната част на влакната. Аркуатните дефекти респектират хоризонталния меридиан поради липсата на прекръстосване и наличието на хоризонтално рафе.

- При засягане на назалните влакна, които навлизат под прав ход в назалната част на папилата, се формира темпорален ветрилообразен дефект, който не респектира хоризонталния меридиан.

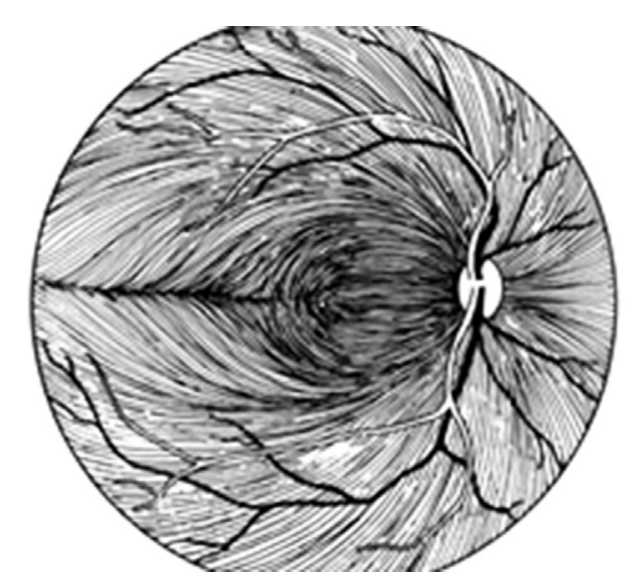

Фиг. 2. Ориентация и ход на неврофибрилите и съдовите дъги в ретината

Патологията на зрителния нерв включва най-често:

1. Съдови заболявания - исхемична оптикопатия (предна/задна)

2. Възпалителни заболявания - папилит и ретробулбарен неврит

3. Невродегенеративни с асцендентна атрофия - глаукома

4. Интоксикации 
5. Компресивни лезии.

Зрителният нерв се кръвоснабдява от клонове на артерия офталмика (a.centarlis retinae и a. cialiares). Кръвоснабдяването на палилата на зрителния нерв се осъществява от 3 съдови зони, които тясно анастомозират: преламинарна, ламинарна и ретроламинарна. Основна роля играят задните къси цилиарни артерии, които осигуряват кръвоснабдяването на диска в трите зони. Клончета на задните къси цилиарни артерии образуват т. нар. артериален пръстен на Zinn-Haller. Исхемичните оптикопатии в зависимост от засегнатите клонове дават алтитудинални дефекти и по-рядко пълно отпадане (наличие на анастомози) монокуларно на зрителното поле. Алтитудиналният дефект при съдова патология е свързан със сляпото петно за разлика от дъговидните скотоми при глаукома, които не са пряко свързани, тъй като следват неврофибриларното разпределение.
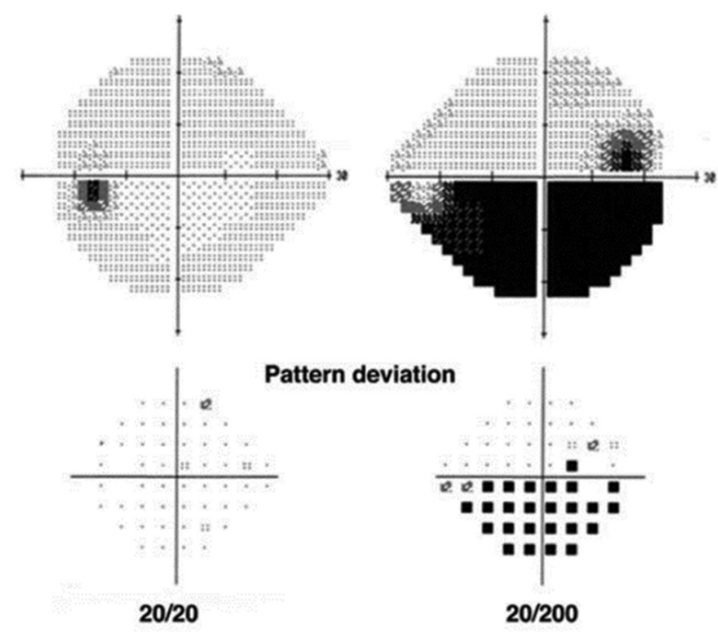

Фиг. 3. Алтитудинален дефект, свързан със сляпото петно (исхемична оптикопатия)

Възпалителните заболявания на зрителния нерв могат да дадат по правило най-различни по форма и дълбочина скотоми - от централен, алтитудинален, монокулярен хемианопсичен дефект до пълно отпадане на зрителното поле. В някои случаи диференциалната диагноза между неврит с алтитудинален дефект и исхемична оптикопатия е трудна.

Характерен за метаноловата интоксикация е двустранният цекоцентрален дефект. Генезата е невродегенерация, свързана с не- достиг на вит. В12. Такова състояние може да се развие и при недоимъчно хранене (резултат от обширна резекция на дебелото черво с ангажиране на цекума; хранителни разстройства, паразитози). Пациенти с цекоцентрални скотоми трябва да бъдат подробно изследвани.

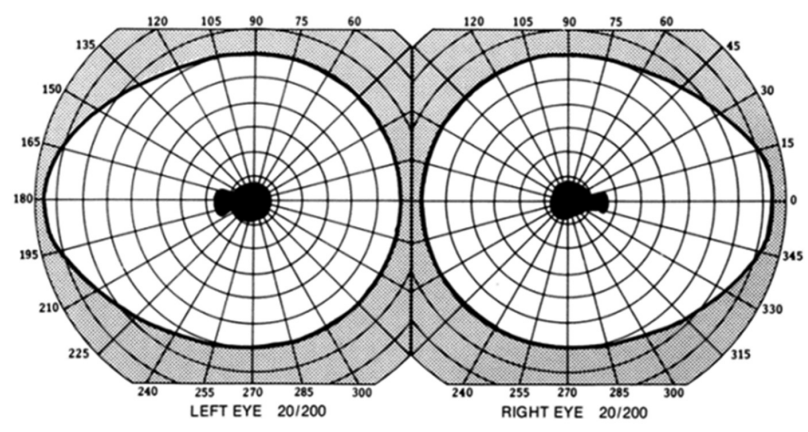

Фиг. 4. Двустранни цекоцентрални скотоми (токсична оптикопатия)

Глаукомата представлява асцендентна атрофия на зрителния нерв и дава характерни аркуатни скотоми. Класифицирани са от различни автори. Според Aulhorn \&Harms (1978) те се дефинират в 5 фази:

Фаза 1. Изменящи се (нестабилни) малки скотоми в зоната на Бжерум (5-25우 от фиксационната точка)

Фаза 2. Дълбоки дефекти в назалната зона

Фаза 3. Дъгообразен скотом, назално стъпало

Фаза 4. Обширен дъговиден или пръстеновиден скотом със запазен централен остров

Фаза 5. Запазено темпорално поле.

Нестабилност в периметричната находка и висока степен на вариабилност могат да бъдат ранен маркер за глаукома, но и за неврологична патология. Изолираната генерализирана депресия на светлочувствителността е рядка при глаукома и не е диагностичен критерий, както и разширеното сляпо петно. Диагностични са назални депресии, респектиращи хоризонталния меридиан (рафето), централни дефекти $\left(30^{\circ}\right)$. Фиксацията влияе върху проекцията на скотомите (лошата фиксация води до недооценяване на дефектите и привидното им задълбочаване при подобряване на фиксацията. Възможни са редки форми на изолирани периферни дефекти, например ветрилообразен темпорален дефект, 
който се дължи на засягане на назалните влакна (не респектират хоризонаталния меридиан).
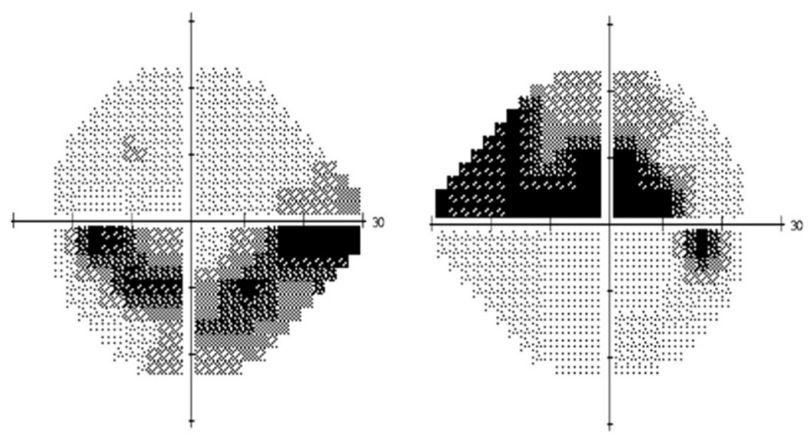

Фиг. 5. Глаукомни дефекти

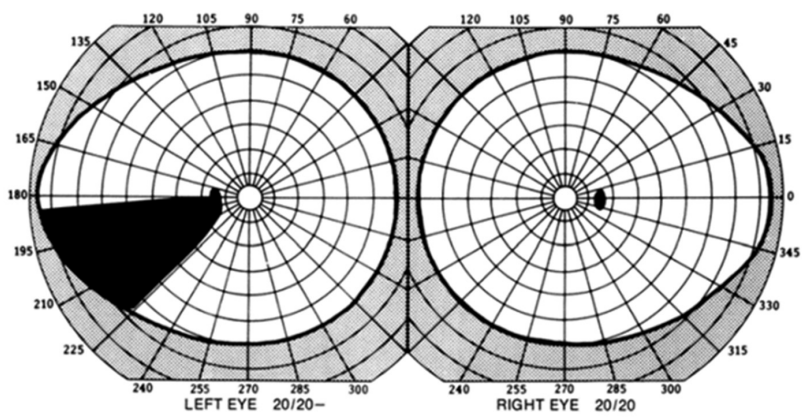

Фиг. 6. Темпорален ветрилообразен дефект при глаукома

Стадирането на глаукомата днес се прави според класификацията на Hodapp.

Много важна е ДД на глаукомната оптиконевропатия. Глаукомата е асцендентна атрофия и трябва да съществува съответствие в морфологичната находка (ОСТ - дефекти в GCC). Липсата на дефекти в ганглийно-клетъчния слой, особено при наличие на периметричен дефект, трябва да насочва към десцендентна атрофия с друга генеза.

Компресивни лезии на зрителния нерв дават скотом с различна форма според локализацията на лезията. Периметричният дефект винаги се съпътства от намалено зрение, екзофталм и често има ангажиране на други черепномозъчни нерви в областта на върха на орбитата или фисура орбиталис супериор.

\section{ХИАЗМАЛЕН ТИП ПЕРИМЕТРИЧНИ ДЕФЕКТИ (ПРАВИЛО НА КРЬСТОСВАНЕТО "RULES OF THE ROAD")}

Лезии в зоната на хиазмата (аденоми на хипофизата, таламични тумори и тумори на четвъртото мозъчно стомахче) дават най-об- що хемианоптични дефекти, които започват от фиксационната точка и респектират вертикалния меридиан. Ретиналната патология и лезиите на зрителния нерв дават дефекти, свързани със сляпото петно (проекция на зрителния нерв) и респектират хоризонталния меридиан. Това правило помага при диференциалната диагноза.
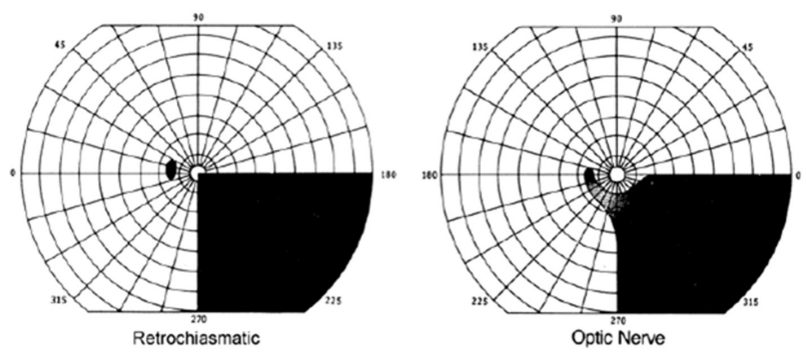

Фиг. 7. ДД между ретрохиазмална лезия - дефектът е свързан с фиксационната точка, и лезия на зрителния нерв - дефектът е свързан със сляпото петно

Ретрохиазмалните лезии не дават намаление на зрението, освен ако не са двустранни, тогава са симетрични и еднакви в двете очи. Когато пациентът има асиметрични хемианоптични дефекти, зрението може да бъде засегнато в различна степен. Това се дължи на засягане на зрителните нерви в зоната на хиазмата. Рядко засягането на зрителния нерв (компресивна или демиелинизираща генеза) може да даде монокуларна темпорална хемианопсия. В тези случаи лезията е много назад и засяга ипсилатералните кръстосани назални влакна, без да се засягат контралатералните.

Правилото "Rules of the road" се базира на анатомични факти:

1. Назалните ретинални влакна се кръстосват и вървят в контралатералния тракт. Темпоралните влакна не се кръстосват - това е причината за битемпоралните хемианопсии при хиазмални лезии.

2. Влакната от долната ретинална половина вървят в латералната част, а тези от горната половина - в медиалната част на зрителния тракт $\left(90^{\circ}\right.$ ротация на влакната от хиазмата в тракта).

3. Долноназалните влакна се кръстосват в хиазмата (Wilbrand knee) и след това преминават назад към некръстосаните долнотемпорални влакна в тракта. Наличието на Wilbrand knee е предпоставка за т.нар. junctional scotoma. В тези случаи зрението на 
пациента е намалено в едното око, а лезията трябва да се търси в контралатералната половина.

4. Макулните влакна се кръстосват в хиазмата и ако са засегнати, може да е налице централна битемпорална хемианопсия.

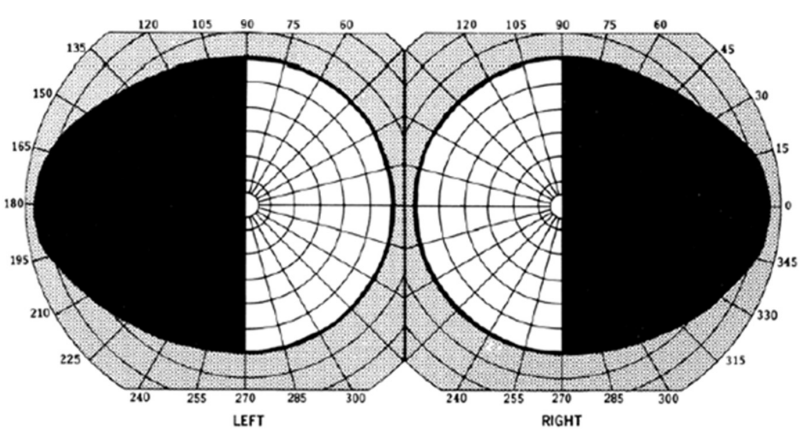

Фиг. 8. Битемпорална хемианопсия (хиазмална лезия)

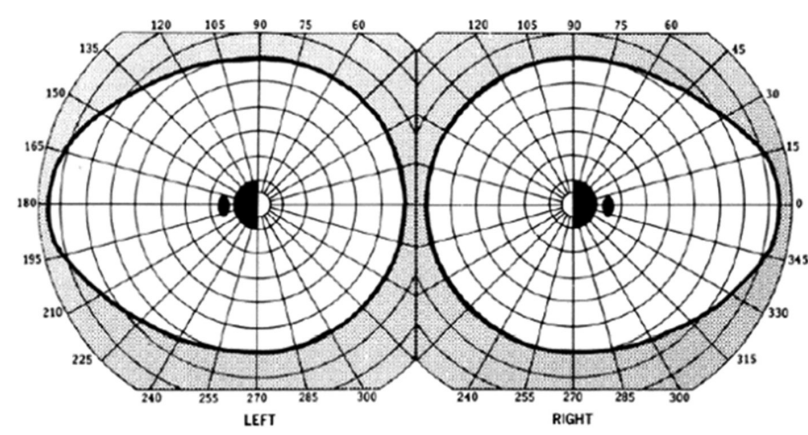

Фиг. 9. Централна битемпорална хемианопсия (хиазмална лезия; ангажиране на макулните влакна)

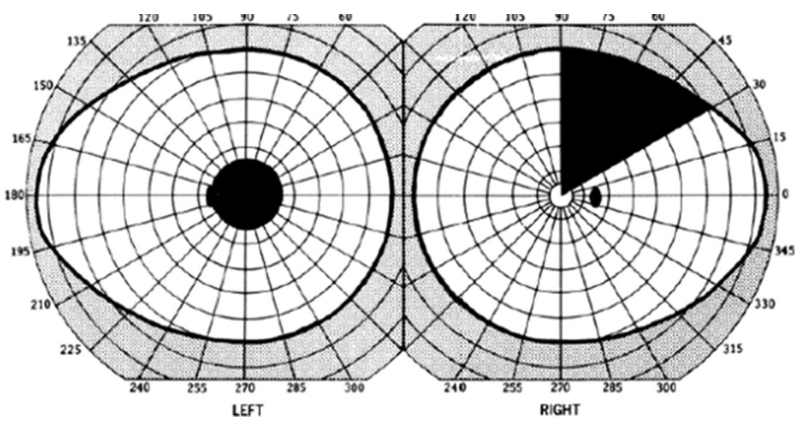

Фиг. 10. Junctional scotoma (хиазмална лезия с ангажиране и на зрителния нерв). Намалено зрение на едното око в резултат от централен скотом и дефект в другото око, респектиращ вертикалния меридиан, трябва да насочва към параселарна патология

Трябва да се диференцира истинската битемпорална хемианопсия от псевдобитемпорална хемианопсия. Тя не респектира вертикалния меридиан и може да се дължи на редица състояния:

- Некоригирана рефрактивна грешка (найчесто астигматизъм)

• Тилтед диск
• Увеличено сляпо петно при папиледем

- Големи цекоцентрални скотоми

- Секторен ретинитис пигментоза (в назалните сектори)

- Блефарохалази

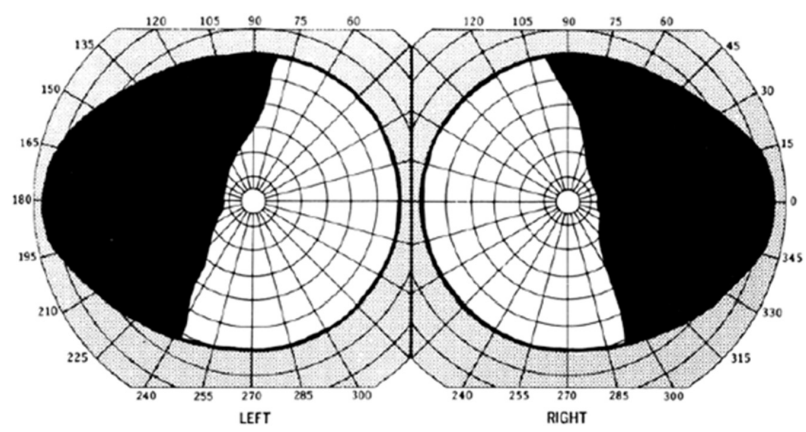

Фиг. 11. Псевдобитемпорална хемианопсия

\section{Биназална хемианопсия}

Повечето назални дефекти се дължат на аркуатни скотоми. Много рядко има истински едностранни или двустранни назални хемианопсии. Те нямат връзка със сляпото петно. Никога не се дължат на хиазмална лезия. Могат да се дължат на притискане на темпоралната част на зрителния нерв и предния ъгъл на хиазмата или в близост до канала на зрителния нерв. В тази локация могат да се засегнат само темпоралните влакна. Причина за такава лезия може да бъде аневризма, тумор (питуитарен аденом), съдов инцидент. В повечето случаи биназалните хемианопсии се дължат на глаукомни дефекти или са артефакт на изследването.

\section{Монокуларна темпорална хемианопсия}

Монокуларната темпорална хемианопсия е рядка находка и може да се дължи на компресивни лезии (питуитарен тумор, краниофарингеом, менингиом; при конгенитални аномалии на зрителния нерв (хипоплазия); неврит на зрителния нерв. Във всички случаи има аферентен зеничен дефект и намаление на зрението. Може да има или да липсва бледост на папилата. Ако липсва зеничен дефект, да се мисли за неорганична причина. Лезията засяга зрителния нерв преди кръстовището на хиазмата.

\section{Синдром на разширеното сляпо петно}

Описва се като внезапна поява на темпорален скотом, центриран в зоната на сляпото петно в едното или двете очи. Често се съпът- 
ства от фотопсии. По-често се среща при жени. Зрителният нерв може да бъде нормален или леко едемен. Засегнатото око може да има лек витриит. ОСТ дава нарушения в овоидната зона. Асоциира се с някои варианти на White dot syndromes: Multiple evanescent white dot syndrome (MEWDS), Multifocal choroiditis (MFC), Accute zonal occult outer retinopathy (AZOOR), Accute macular neuroretinopathy (AMN). Етиологично се приема, че се касае за фоторецепторна дисфункция с неясна генеза - възможно вирусна или стресогенно обусловена.
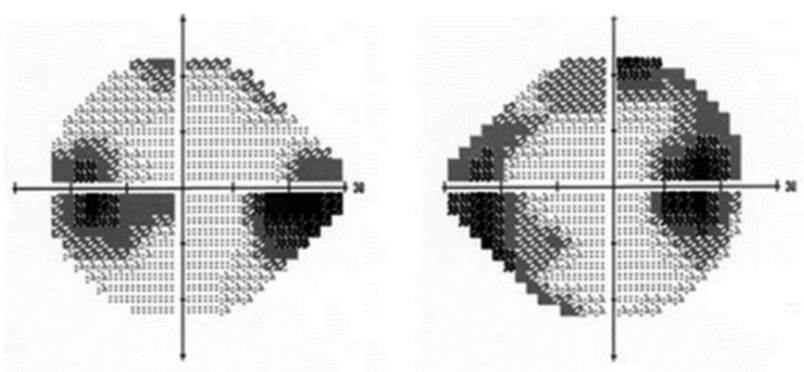

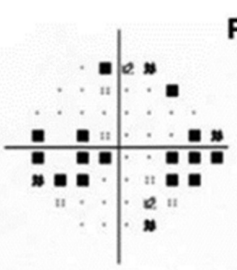

20/25

Фиг. 12. Разиирено сляпо петно

\section{Tractus opticus/Corpus geniculatum laterale (CGL)}

Всички ретрохиазмални лезии водят до контралатерални хомонимни хемианопсии. Конгруентността (сходство в дефекта - локация, големина, дълбочина, наклон) е важен критерий. Колкото по-назад е дефектът, толкова по-изразена е конгруентността.

Трактусовият синдром се характеризира с триадата:

- Неконгруентна хомонимна хемианопия

- Атрофия на зрителния нерв тип папионка или билатерална атрофия в RNFL

- Аферентен зеничен дефект (контралатерално на страната на лезията), зеница на Wernicke (осветяване на зеницата в засегната половина не дава зенична реакция, докато осветяване на другата половина дава зенична реакция) или зеница на Behr - анизокория с по-широка зеница от страната на хемианопсията.
За лезии в корпус геникулатум латерале (LGN) е характерна неконгруентна хомонимна хемианопия, когато се касае за туморен процес и характерни секторни дефекти при съдови инциденти в резултат на двойното кръвоснабдяване от предната и задната хороидална артерия.

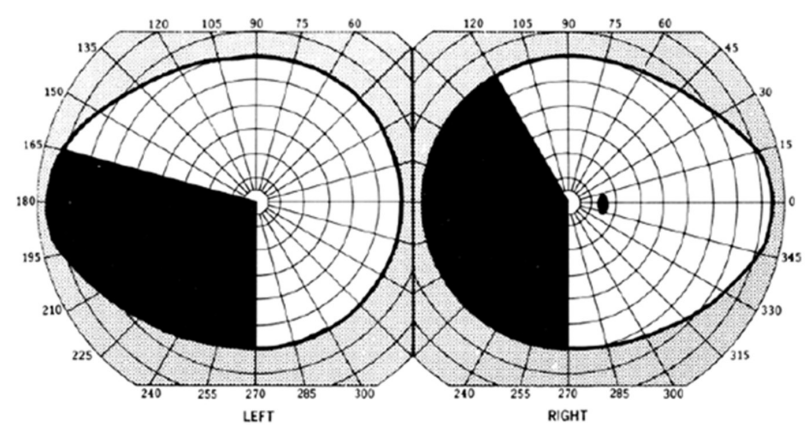

Фиг. 13. Инконгруентна левостранна хемианопсия (трактусова лезия)

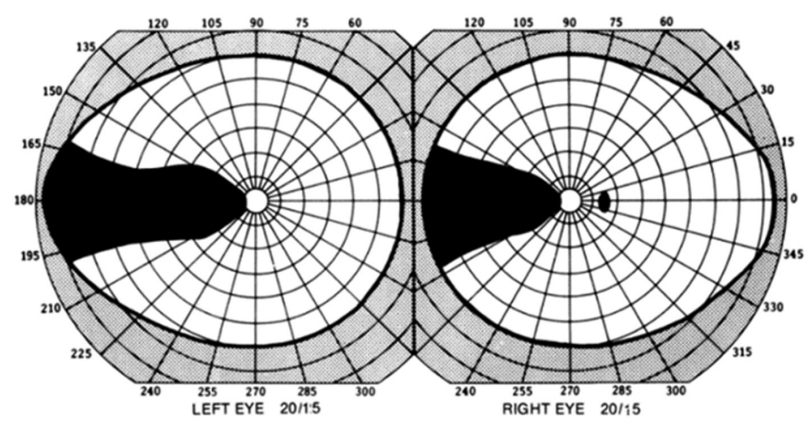

Фиг. 14. Оклузия на задна хороидална артерия

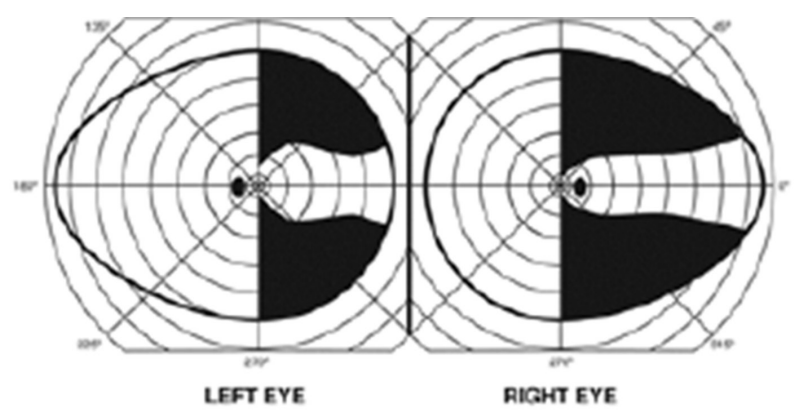

Фиг. 15. Оклузия на предна хороидална артерия

\section{Темпорален и париетален лоб (долно-горно разделяне)}

Долните нервни влакна (ипсилатералните долнотемпорални и контралатералните долноназални) преминават от корпус геникулатум латерале към предната част на темпоралния лоб, оформяйки Meyer loop $(2.5 \mathrm{~cm})$. Горните ретинални влакна вървят към радиацио оптика на париеталния дял (ипсилатералните горнотемпорални и контралатералните горноназал- 
ни влакна). Макулните влакна навлизат само частично в темпоралния лоб. Лезии на предния темпорален лоб дават периферна контралатерална хомонимна горна квадрантанопсия ("pie in the sky"). По-обширни лезии ще дадат инконгруентна хемианопсия, по-плътна в горните квадранти. Лезии в париеталния дял дават контралатерална долна хомонимна квадрантанопсия или хомонимна хемианопсия, по-плътна долу. Често е налице и погледна парализа - при опит за Bell феномен се получава девиация по посока, обратна на париеталната лезия. За лезиите в париеталния дял е характерна асиметрия в OKN - отслабен от страната на лезията. Друга важна особеност на церебралните лезии след corpus geniculatum laterale е липсата на офталмоскопска бледост на папилата.
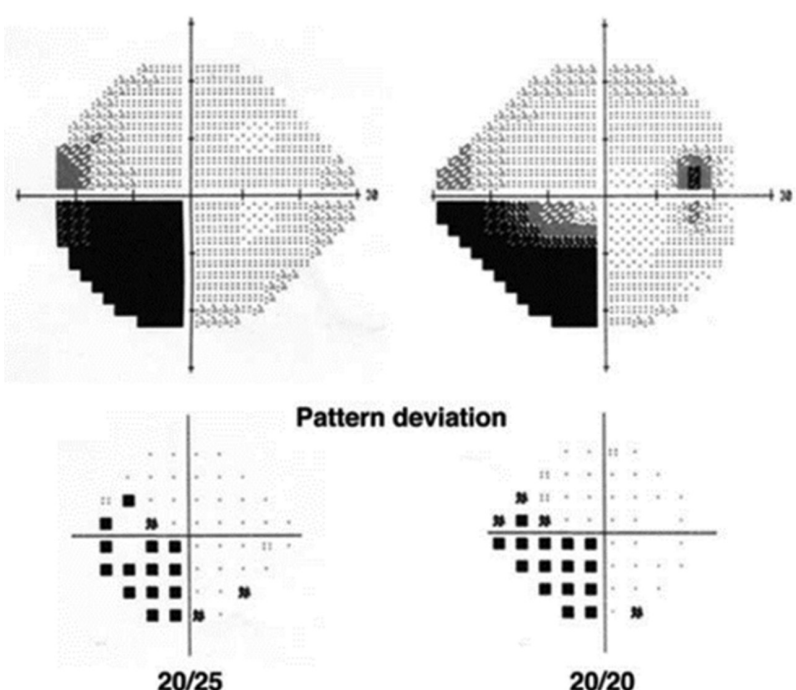

Pattern deviation
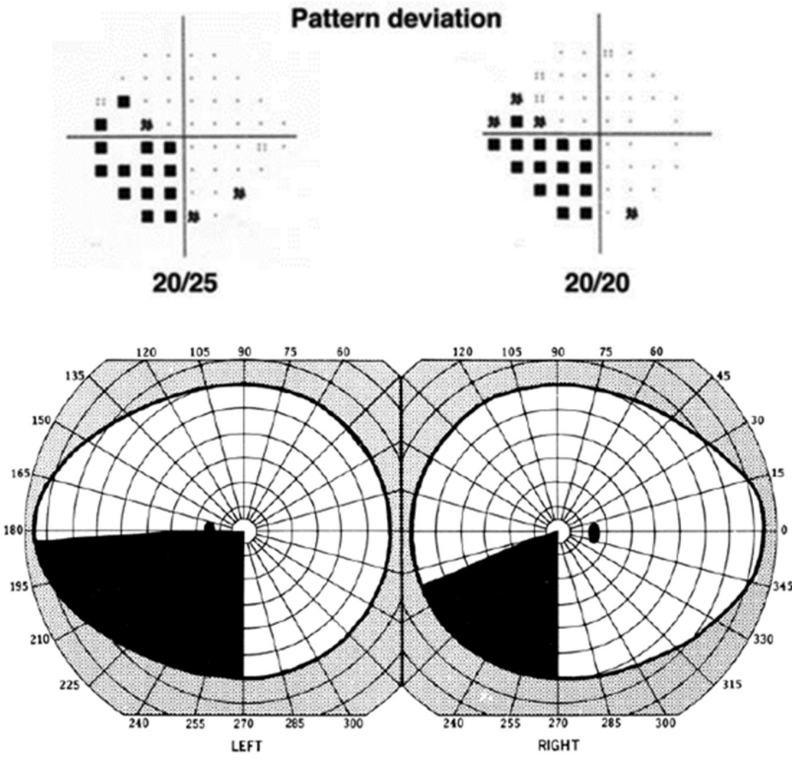

Фиг. 16 а,б. Долна левостранна квадрантанопсия париетална (Pie on the floor)

\section{ПЕРИМЕТРИЧНИ ДЕФЕКТИ ПРИ ЛЕЗИИ В ОКциПиТАЛНИЯ дЯЛ}

При засягане на окципиталния дял могат да се наблюдават следните периметрични дефекти:

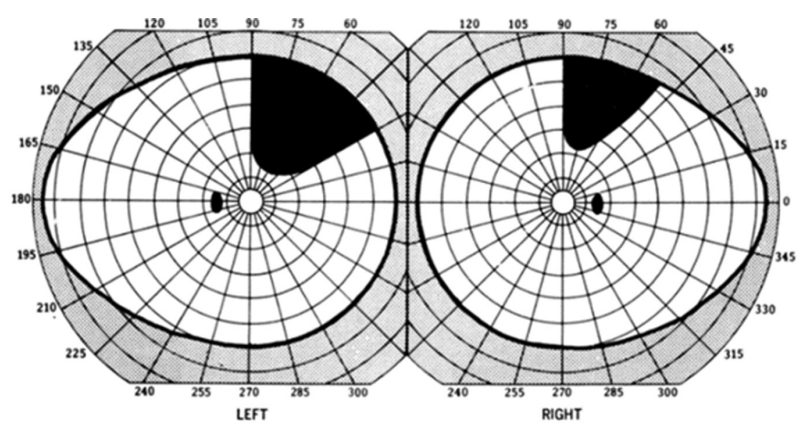

Фиг. 17. Десностранна горна квадрантанопсия - лезия в ляв темпорален лоб (Pie in the sky)

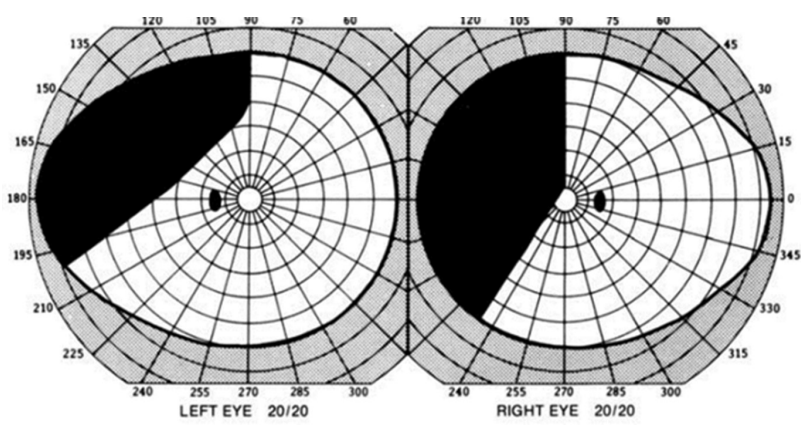

Фиг. 18. Левостранна хемианопсия, по-плътна в горния квадрант - лезия в десен темпорален лоб

- Централна хомонимна хемианопсия

- Хомономна хемианопсия с макулно запазване

- Двустранни хомонимни хемианопсии с макулно запазване (концентрично стеснение)

- Двустранни хомонимни квадрантанопсии (шахматен тип)

- Хемианопсии със запазване на темпоралния сърп

- Отпадане на темпоралния сърп (монокулярно).

В зрителния кортекс макулата се проектира на върха на окципиталния дял. Лезия в тази зона (най-често ПЗВЧП) дава изолирана централна хомонимна хемианопсия. Запазване на макулата най-често се получава при съдови инциденти в окципиталния дял. Макулната зона има двойно кръвоснабдяване от крайни клонове на a. cerbri posterior и a. cerebri media. Кортикалното представителство за крайна и средна периферия се кръвоснабдява само от задната церебрална артерия. При генерализирана хипоперфузия (интраоперативна хипотензия) или след реперфузионен синдром (след инсулт) предилекционно се засягат крайните артериални разклонения. В тези случаи може да се наблюдават изоли- 
рана централна хомонимна хемианопсия или двустранни централни скотоми.

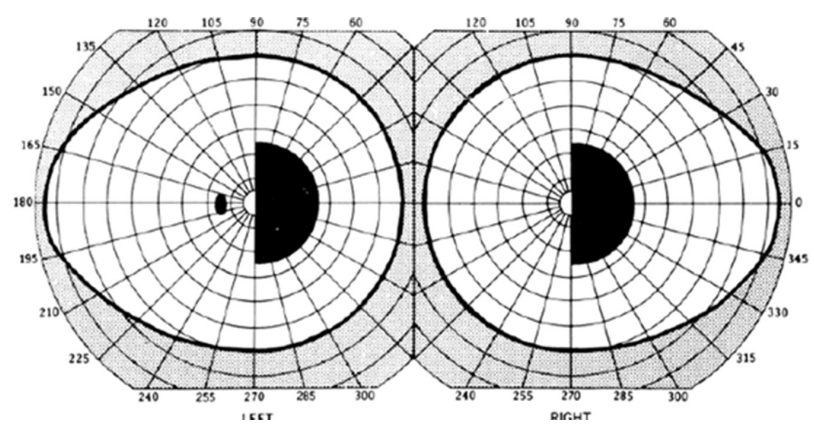

Фиг. 19. Десностранна централна хемианопсия (лезия вляво на върха на окципиталния дял)

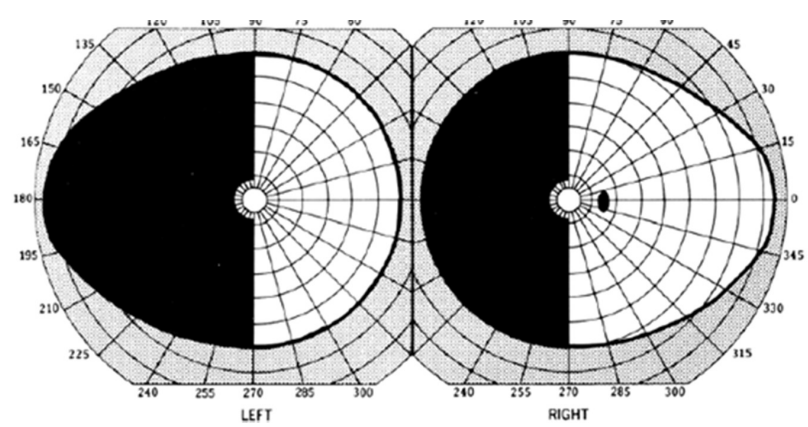

Фиг. 20. Левостранна хемианопсия с макулно запазване (окципитален дял)

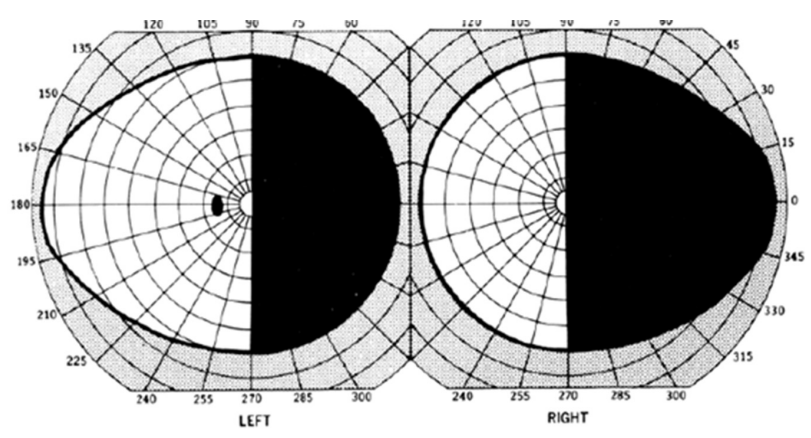

Фиг. 21. Пълна десностранна хомонимна хемианопсия с ангажиране (разцепване) на макулата

Билатералната хомонимна хемианопсия с макулно запазване практически дава концентрично ограничено периферно зрение с нормален фундус. Най-често е резултат от обширни съдови инциденти в басейна на задната церебрална артерия. При лезии в окципиталния дял липсва бледост на папилата. В ДД на концентричното стеснение на периферното зрение влизат пигментният ретинит, глаукомата, хороидеремията, PRALC. В тези случаи се наблюдават видими офталмоскопски белези. Перихиазмалният арахнит протича с концентрично стеснение на зрението, но е налице атрофия на папилите. След застойни папили и наличие на вторична атрофия също може да има концентрично стеснение на зрението. Може да се дължи и на неорганична загуба на зрението.

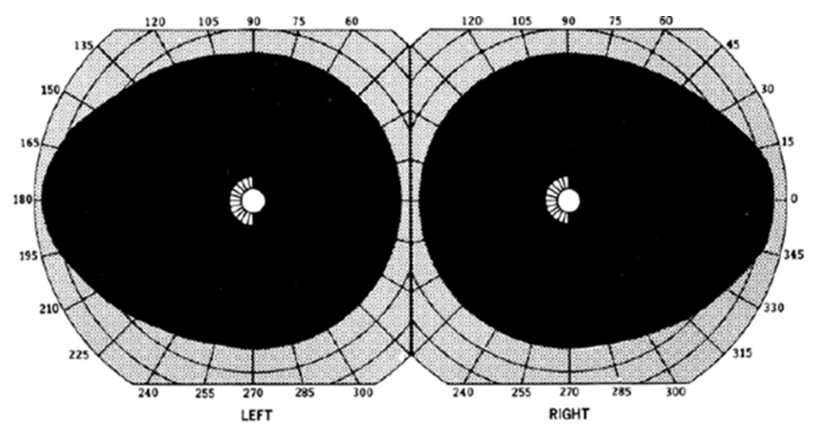

Фиг. 22. Двустранна хомонимна хемианопсия с макулно запазване

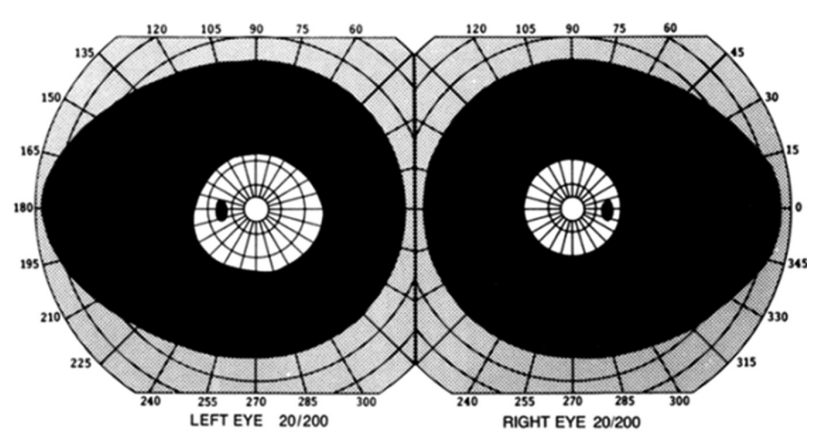

Фиг. 23. Концентрично стеснение на зрителните полета двустранно

\section{темпорален сърп}

Двете зрителни полета се припокриват в централните $60^{\circ}$. Всяко око има темпорален сърп монокулярно, който съответства на назалната ретина и се проектира в контралатералния зрителен кортекс в зоната на фисура калкарина. Ако пациент има хомонимна хемианопсия със запазване на темпоралния сърп, лезията е разположена със сигурност в окципиталния дял. Само там има разделяне на назалните от темпоралните зони.

Възможно е също изолирано засягане на темпоралния сърп монокулярно. ДД в тези случаи е с неврит на зрителния нерв и компресивна оптикопатия.

\section{Оптокинетичен нистагъм (OKN)}

Погледните и проследяващите движения могат да помогнат в топичната диагностика на церебралните лезии. Хоризонталните погледни центрове са ситуирани в понса. Зри- 


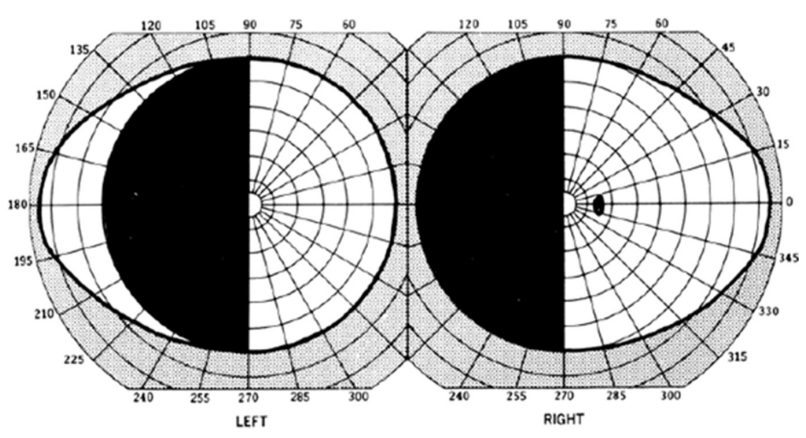

Фиг. 24. Левостранна хомонимна хемианопсия със запазване на темпоралния сърп
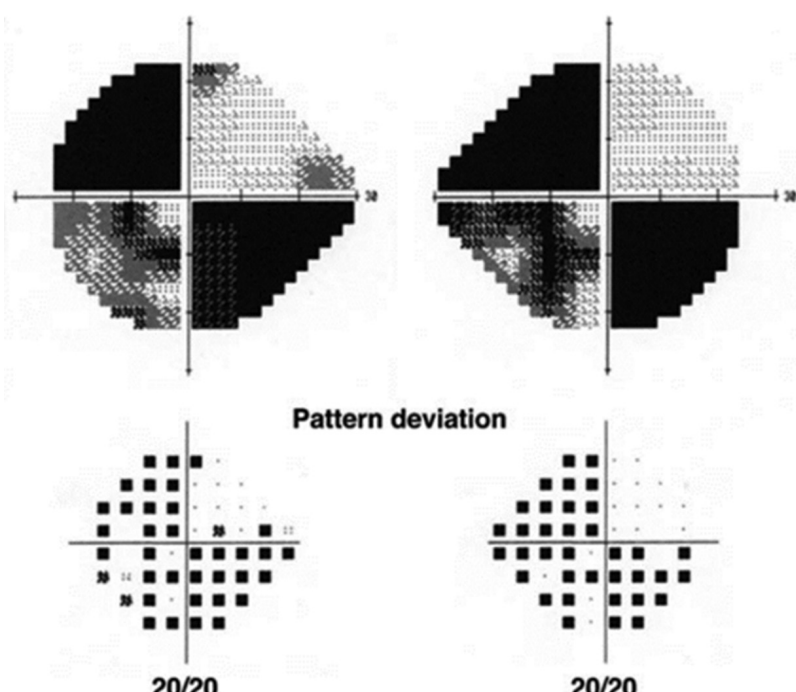

Фиг. 25. Двустранна квадрантанопсия - левостранна горна + десностранна долна - т.нар. „Шахматен скотом“ при двустранни окципитални лезии

телният път, започващ от дясната церебрална половина, завършва в десния понс и генерира погледни движения вдясно и обратно.

- Пациент с хомонимна хемианопсия и лезия в трактуса, темпоралния лоб или окципиталния дял няма да има нарушение в погледните движения. OKN ще бъде симетричен.

- Пациент с хомонимна хемианопсия и лезия в париеталния дял ще има затруднение при поглед към страната на увредата и ще има асиметричен OKN (отслабен от страната на лезията).

\section{Правило на Cogan}

При хомонимна хемианопсия + асиметричен OKN - вероятно тумор в париеталния дял

При хомонимна хемианопсия + симетричен OKN - вероятно лезия в окципиталния лоб (най-често инсулт).
И накрая вместо заключение, можем да обобщим диференциалнодиагностичните аспекти, в зависимост от вида на скотома.

Ring scotoma (пръстеновиден скотом)

- Retinitis pigmentosa

- Glaucoma

- Drug toxicity

Концентрично стесняване на периферното зрение

- Глаукома

- Периневрит

- Оптохиазмален арахнит

- Retinitis pigmentosa

- PRALC (панретинална фотокоагулация)

- Съдов инцидент в басейна на задна церебрална артерия

- Вторична атрофия на зрителните нерви (след застойни папили).

Централен скотом (едностранен/двустранен)

- Ретробулбарен неврит

- Макулна патология (CNV, атрофия, конусчева дистрофия)

- Хлорокинова интоксикация

- Хиазмени лезии

- Локализиран дефект в окципиталния дял.

Дъговиден (аркуатен) скотом

- Глаукома

- Съдови заболявания на ретината

- Юкстапапиларен хориоретинит

- Юкстапапиларно CNV

- Съдови оклузии, засягащи a. carotis, a. ophthalmica

- Менингиом на dorsum sellae и foramen opticum

- Друзи на папилата

- Перипапиларна атрофия при миопия.

Алтитудинален дефект

- Съдови оклузии на ретиналните съдове (респектират хоризонталното рафе)

- Прехиазмален синдром

- Исхемична оптикопатия (при задните исхемични оптикопатии: долна - a. crebri ant.; горна - a. carotis int.)

- Менингиом на tuberculum sellae

- Оптохиазмален арахнит

- Ретробулбарен неврит

- Псевдотумор на мозъка. 


\section{Увеличено сляпо петно}

- Перипапиларна атрофия

- Друзи на папилата

- Някои форми на Wight Dot Syndrom

- Следзастойни папили.

Temporal crescent syndrome (монокулярно)

- Глаукома

- Лезия в предната част на окципиталния лоб

- Ранна хипофизарна лезия.

Битемпорална хемианопсия

- Параселарни лезии.

Биназални хемианопсии

- Артефакт

- Глаукома

- Хиазмални лезии - засягане на кръстосани и некръстосани влакна дава и темпорално стеснение в полето на едното око
- Двустранни туморни лезии (асиметрия)

- Двустранни аневризми.

Да не забравяме, че диагностиката е комплексен процес. Изисква преди всичко знания

- виждаме това, което знаем.

\section{кНигопиС}

1. Racette L, Fischer M, Bebie H et al. Visual field digest (A guide to perimetry and the Octopus perimeter) 7 th edition, 2018.

2. Foroozan R, Vaphiades MS. Neuro-ophthalmology review manual, 8th edition, Slack Inc., 2018.

3. Terminology and guidelines for glaucoma, EGS, 4th edition, 2014.

4. Miller NR, Subramanian PS, Patel VR. Clinical Neuro-Ophthalmology. The Essentials, Third edition, Wolters Kluwer, 2016.

5. Walsh TJ. The interpretation of visual fields. A Manual, AAO, 1979. 